\title{
Pawet Czechowski
}

ORCID: 0000-0002-7124-5780

\section{Metody badania prawa rolnego według koncepcji Profesora Andrzeja Stelmachowskiego}

W 2019 r. minęło dziesięć lat od śmierci Profesora Andrzeja Stelmachowskiego - współtwórcy i nestora nauki prawa rolnego w Polsce. Koncepcja badania prawa rolnego upowszechniona przez niego była nowatorska i dynamiczna.

Ten wybitny badacz prawa cywilnego, a następnie prawa rolnego, twierdził, że w odróżnieniu od prawa cywilnego prawo rolne nie wykształciło własnej metody regulacji prawnej ${ }^{1}$. Prawo rolne w ramach przyjętej metody wymagało wyodrębnienia kryteriów dotyczących przedmiotu regulacji ${ }^{2}$, jak również określenia i zdefiniowania metod regulacji prawnej ${ }^{3}$. Badając normy, instytucje i zjawiska prawa, Profesor Stelmachowski posługiwał się równolegle metodą cywilnoprawną i administracyjnoprawną. Jako badacz prawa sformułował tezę, że prawo rolne, pomimo wyodrębnienia w sferze legislacyjnej pokaźnego zbioru regulacji prawnych, nie wykrystalizowało odrębnej, usystematyzowanej regulacji prawnej. Prawo rolne, jak twierdził, nie ma części ogólnej, jak

${ }^{1}$ A. Stelmachowski, Przedmiot i źródła prawa rolnego, w: P. Czechowski, M. Korzycka-Iwanow, S. Prutis, A. Stelmachowski, Polskie prawo rolne na tle ustawodawstwa Unii Europejskiej, wyd. 2, Warszawa 1997, s. 9.

${ }^{2}$ R. Budzinowski, Profesor Andrzej Stelmachowski jako agrarysta, „Studia Juridica Agraria" 2011, t. IX, s. 97-105; A. Lichorowicz, Pojęcie i przedmiot prawa rolnego, w: A. Stelmachowski (red.), Prawo rolne, Warszawa 2009, s. 23-38; R. Budzinowski, Pojęcie i przedmiot prawa, w: P. Czechowski (red.), Prawo rolne, Warszawa 2019, s. 27-41; P. Czechowski, M. Korzycka A. Niewiadomski, Ewolucja ustawodawstwa prawnorolnego, w: P. Czechowski (red.), Prawo rolne, s. 42-55.

${ }^{3}$ Por. A. Stelmachowski, Zarys teorii prawa cywilnego, Warszawa 1988, s. 19, powołujący się na konstrukcję trzech szkół badania prawa: H.J. Berman, Law and Logos, „DePaul Law Review" 1994, vol. 44, s. 143 i n. 
np. prawo cywilne. Mimo to ustalono zasady prawa rolnego, których swoistym nośnikiem wartości są normy prawne.

Zasady prawa rolnego stanowią podstawę doktrynalnego wyodrębnienia prawa rolnego jako samodzielnej, kompleksowej gałęzi prawa. Podlegają one ewolucji, lecz ich rdzeń pozostaje niezmienny ${ }^{4}$.

Stelmachowski poprzez funkcjonalne podejście do badania prawa, w tym prawa rolnego, ukazał jego ścisły związek z działalnością gospodarczą, a zwłaszcza interwencyjną rolą państwa w sektorze rolnym. Wskazywał na związek polityki, gospodarki i prawa w aspekcie jego stosowania, analizując zarazem społeczne skutki regulacji prawnych5 ${ }^{5}$.

$\mathrm{W}$ analizie regulacji prawa cywilnego i prawa rolnego często posługiwał się równolegle metodami wielkich szkół badania prawa ${ }^{6}$, to jest pozytywistyczną, prawno-naturalną oraz historyczną.

W szkole pozytywistycznej metodologii nauki prawa można wyróżnić dwa nurty. Pierwszy z nich to tzw. jurysprudencja pojęciowa, oparta na wnioskowaniu formalno-dogmatycznym, z wyłączeniem rozważań problemu celowości. Promotorem tej szkoły był H. Kelsen, twórca normatywizmu, autor teorii czystej nauki prawa?

Drugi nurt związany był z badaniem norm prawa pod kątem ich celowości. Jej głównym reprezentantem był $\mathrm{R}$. von Jhering. $\mathrm{Z}$ tego kierunku badań wywodzi się metodologia badania prawa, znana pod nazwą jurysprudencji interesów. Ten drugi kierunek był niewątpliwie bliższy pracy badawczej Profesora Stelmachowskiego. Nie bez przyczyny często cytował on von Jheringa, zwłaszcza w swoich pracach cywilistycznych ${ }^{8}$. Profesor omawiał także problem celu regulacji prawnych, postrzegając prawo jako instrument realizacji celów społecznych ${ }^{9}$. Zainteresowanie tą kwestią widać w pracach z zakresu teorii prawa cywilnego, w szczególności dotyczących zasad prawa cywilnego, klauzul generalnych w Kodeksie cywilnym, źródeł prawa cywilnego, problematyki

${ }^{4}$ P. Czechowski, A. Stelmachowski, Zasady prawa rolnego, „Państwo i Prawo” 1979, z. 12, s. 30-38; A. Lichorowicz, Pojęcie i przedmiot prawa rolnego. Miejsce prawa rolnego w polskim systemie prawa, w: A. Stelmachowski (red.), Prawo rolne, s. 30-31; P. Czechowski, Zasady prawa rolnego stabilizacja czy ewolucja?, „Studia Juridica Agraria” 2011, t. IX, s. 107-113.

${ }^{5}$ R. Budzinowski, Profesor Andrzej Stelmachowski.., s. 103.

${ }^{6}$ A. Stelmachowski, Zarys teorii..., s. 19.

7 H. Kelsen, Czysta teoria prawa, Warszawa 2014.

${ }^{8}$ R. von Jhering, Zweck im Recht, Leipzig 1893; idem, Geist des römischen Rechts, Leipzig 1926. Por. cytowanie prac R. von Jheringa przez A. Stelmachowskiego: Zarys teorii... ss. 16, 54-171, 254.

9 Por. przykładowo monografie: A. Stelmachowski, Przysposobienie w prawie rodzinnym, Warszawa 1957; idem, Istota i funkcja posiadania, Warszawa 1958; idem, Kontraktacja produktów rolnych, Warszawa 1960; idem, Odpowiedzialność cywilna za niedobory, Warszawa 1966. 
osób prawnych czy nowatorskiej analizy pozakonstytucyjnych źródeł prawa, tworzonych na podstawie orzecznictwa Sądu Najwyższego czy arbitrażu gospodarczego ${ }^{10}$. Teza o prawotwórczej roli orzecznictwa sądowego i gospodarczego wskazuje, że orzeczenia sądowe tworzą normy ogólne w drodze, jak się okazało, „linii orzeczniczej”, niekoniecznie wynikającej z przepisów ustawy, i funkcjonują tak, jakby miały za sobą autorytet ustawy.

Teza ta, wywiedziona $\mathrm{z}$ celowościowej analizy prawa w połowie lat 60 . ubiegłego wieku, wywołała polemikę naukową, zwłaszcza ze strony teoretyków prawa reprezentujących socjalistyczny kierunek neopozytywizmu normatywnego. Z perspektywy lat teza o prawotwórczej roli sądów i arbitrażu okazała się trafna ${ }^{11}$.

Profesor Stelmachowski poszukiwał celu i funkcji w regulacjach prawnych tworzących fundamenty instytucji prawa cywilnego, co pokazują jego badania nad prawem własności, jego funkcjami oraz konstrukcją ${ }^{12}$.

$\mathrm{Na}$ gruncie tych badań Profesor Stelmachowski, analizując ujęcie celu, funkcji oraz przedmiotu indywidualnej własności rolnej w powiązaniu z kodeksową treścią własności, sformułował koncepcję własności rolniczej jako kompleksu praw i obowiązków, która stanowi jedną z podstaw doktrynalnych współczesnego polskiego prawa rolnego ${ }^{13}$.

Zgodnie $\mathrm{z}$ tą koncepcją, właściciel gospodarstwa rolnego ma $\mathrm{w}$ odniesieniu do innych podmiotów nie tylko prawa, lecz również określone obowiązki. Poprzez celowościową analizę norm prawa Stelmachowski wskazał, że takie ujęcie własności rolniczej pozwala na ujawnienie konglomeratu przepisów różnej rangi, kształtującego treść prawa własności i sposób jego wykonywania.

Profesor Stelmachowski stosował celowościową metodę badania prawa w szeregu monografii, które stanowią obecnie istotny dorobek doktryny ${ }^{14}$.

${ }^{10}$ Por. A. Stelmachowski, Wstęp do teorii prawa cywilnego, Warszawa 1969, wyd. 2: 1984; idem, Zarys teorii prawa cywilnego, Warszawa 1998.

${ }^{11}$ P. Czechowski, M. Korzycka-Iwanow, S. Prutis, Wspomnienie o Profesorze Andrzeju Stelmachowskim w: A. Stelmachowski (red.), Prawo rolne, Warszawa 2009 s. 7-8.

12 A. Stelmachowski, Wstęp do teorii..., s. 220-227; A. Stelmachowski, B. Zdziennicki, Prawo rolne, Warszawa 1998, s. 225; A. Stelmachowski, w: T. Dybowski (red.), Prawo rzeczowe. System prawa prywatnego, Warszawa 2003, s. 61-405.

${ }_{13}$ M. Korzycka, S. Prutis, Wtasność rolnicza wedtug koncepcji Profesora Andrzeja Stelmachowskiego w: P. Czechowski (red.), Prawo rolne, wyd. 5, Warszawa 2019 s. 56-60.

${ }^{14}$ M. Korzycka, Ochrona własności rolniczej, Warszawa 1979; W. Pańko, Własność gruntowa w planowej gospodarce przestrzennej. Studium prawne, Katowice 1978, s. 28-68; S. Prutis, Instrukcje podstawowe prawa prywatnego (w opozycji do regulacji prawa publicznego), Białystok 2018, s. 319 i n.; M. Korzycka, Prawo własności rolniczej, w: M. Korzycka (red.), Instytucje prawa rolnego, Warszawa 2019, s. 44 i n.; K. Marciniuk, Prawne instrumenty ingerencji władzy 
W swoich badaniach Profesor uwzględniał również metodę szkoły prawno-naturalnej i, akceptując jej podstawy aksjologiczne, badał również określone cele prawa wyznaczone przez porządek naturalny oraz określone wartości. Był entuzjastą badań empirycznych, czyli obserwacji, jak prawo działa w praktyce.

Często podkreślał, że bliscy mu byli przedstawiciele funkcjonalizmu amerykańskiego. Prowadzone pod Jego kierunkiem badania w Dolnośląskim Okręgu Miedziowym w latach 70. ubiegłego wieku ujawniły, że proces rozdrobnienia gospodarstw rolnych, a tym samym struktury agrarnej polskiej wsi, został znacznie ograniczony po wejściu w życie przepisów o obrocie nieruchomościami rolnymi, zamieszczonymi w Kodeksie cywilnym z $1964 \mathrm{r}^{15}$

Kierowane przez Profesora Stelmachowskiego kompleksowe badania nad prawem w działaniu znalazły wyraz w monografiach pod jego redakcją, dotyczących m.in. wpływu instrumentów prawnych na gospodarowanie ziemią rolną w rejonach uprzemysłowionych ${ }^{16}$, a także w wybranych regionach kraju $^{17}$.

W pracach tych nie tylko podjęto problematykę wybranych instrumentów prawnych, lecz także przedstawiono kwestie prawne na tle ekonomiczno-gospodarczym, socjologicznym i przestrzennym. Interdyscyplinarny charakter prowadzonych badań z pewnością przyczynił się do nowego spojrzenia na prawo, w tym prawo rolne, w doktrynie. Utorowało to drogę badaniu problemów granicznych prawa rolnego, związanych m.in. z rozwojem warunków rolnych, obszarów wiejskich, pomocy publicznej dla rolnictwa, ochroną środowiska i konfliktów prawnych na płaszczyźnie rolnictwo - środowisko, w tym prawa leśnego czy prawa żywnościowego.

Problematyka ta stała się szczególnie aktualna po wejściu Polski do Unii Europejskiej. Zaprezentowana została w przygotowanych pod redakcją Profesora Stelmachowskiego ogólnopolskim podręczniku akademickim prawa rolnego, którego autorami byli przedstawiciele wiodących ośrodków uniwersyteckich w Polsce.

Profesor posługiwał się również metodą historycznoprawną. Doskonały przykład zastosowania tej metody stanowi praca zbiorowa wydana pod jego

publicznej w obrót nieruchomościami rolnymi jako środki ksztattowania ustroju rolnego, Białystok 2019, s. 30-68.

15 A. Stelmachowski (red.), Wpływ uprzemystowienia na stosunki własnościowe $w$ rolnictwie w Legnicko-Glogowskim Okręgu Miedziowym, Warszawa 1972.

16 Por. np. Przemiany własności ziemi w rolnictwie polskim, Warszawa 1974; Problemy zarzadzania rejonami uprzemystowionymi, Warszawa 1986.

${ }^{17}$ A. Stelmachowski (red.), Wplyw instrumentów prawnych na przestrzenna strukturę rolnictwa w Polsce, Warszawa 1977. 
redakcją, dotycząca ewolucji pozycji właściciela indywidualnego gospodarstwa rolnego w PRL ${ }^{18}$.

W monografii tej analizie historycznoprawnej poddano szereg mechanizmów prawnych kształtowania statusu prawnego właściciela gospodarstwa rolnego w ramach przyjętych okresów (periodyzacji) polityki rolnej państwa w okresie 40-lecia PRL i jej wpływu na kształtowanie prawa. Stelmachowski przyjął w swojej analizie trzy zasadnicze kryteria (hipotezy): swobody działania gospodarczego, równouprawnienia i gwarancji rozwoju.

Przeprowadzona analiwna ukazała cykliczność działania określonych rozwiązań prawnych, charakteryzujących się w istocie powrotem do pierwotnych rynkowych mechanizmów działania prawa.

Kolejna teza wskazywała, że gwarancja rozwoju oraz jego równoprawność była przez okres 40-lecia PRL niedostateczna, co znacznie przyczyniło się do powstania kryzysu gospodarczego w końcu lat 80., który wstrząsnął podstawami państwowości i doprowadził do demokratycznych przekształceń ustrojowych.

Analiza prac naukowych Profesora Stelmachowskiego dowodzi, że te trzy metody badania prawa znalazły odzwierciedlenie w metodyce jego warsztatu naukowego.

Wszystkie prace naukowe Profesora miały jasno sprecyzowany temat badawczy. Dla analizy problemu formułował zawsze hipotezy, aby syntetyzować prowadzone badania, zwłaszcza w aspekcie problemów granicznych (interdyscyplinarnych), współistniejących jako odrębne kategorie heterogeniczne. Dbał również o kompozycję treści i płynność prowadzonych analiz, co znajdowało odzwierciedlenie w harmonii odbioru tekstu. Starannie dobierał bibliografię naukową (w zależności od przyjętej metody), również w aspekcie prawno-porównawczym.

Zwieńczeniem opracowań naukowych Profesora Stelmachowskiego były tezy końcowe, stanowiące kwintesencję przeprowadzonych analiz badawczych i podsumowań naukowych.

Działalność naukowa Profesora, jego osobowość, a zwłaszcza multidyscyplinarność analizy prawa w działaniu silnie wpłynęły na ukształtowanie szkoły funkcjonalnego badania prawa rolnego przez szerokie grono jego uczniów.

${ }^{18}$ A. Stelmachowski (red.), Ewolucja pozycji właściciela indywidualnego gospodarstwa rolnego w PRL, Warszawa 1989. 


\title{
RESEARCH METHODS IN THE STUDY OF AGRICULTURAL LAW ACCORDING TO THE CONCEPT OF PROFESSOR ANDRZEJ STELMACHOWSKI
}

\begin{abstract}
Sum mary
The deliberations are devoted to the methods of legal research that Professor Andrzej Stelmachowski conducted in the field of agricultural law. This outstanding civil lawyer and co-creator of agricultural law as a separate branch within the system of law used methods that shaped the philosophical schools of law research methodology, that is, the positivist, natural law and historical law school. Using the methodology of these schools, Professor Stelmachowski created an interesting conglomerate of methods of studying law through the analysis of the purpose of a legal norm, the empirical study of law in action and the historical and legal analysis of the evolution of legal institutions. The multithreaded method of legal research adopted by Professor Stelmachowski created a specific methodology of agricultural law research, which constitutes a significant legacy of the doctrine of agricultural law in Poland.
\end{abstract}

\section{METODI DI STUDIO DEL DIRITTO AGRARIO ELABORATI DAL PROFESSOR ANDRZEJ STELMACHOWSKI}

\section{Riassunto}

Le considerazioni svolte si concentrano sui metodi di studio del diritto, che il Professor Andrzej Stelmachowski ha sviluppato nell'ambito del diritto agrario. Questo eccezionale avvocato civilista e co-creatore del diritto agrario come ramo separato all'interno del sistema giuridico si è avvalso dei metodi che hanno influenzato le scuole filosofiche dedite alla metodologia riguardante lo studio in oggetto, vale a dire la scuola positivista, giuridico-naturale e storico-giuridica. Il Professor Stelmachowski, prendendo spunto dalla metodologia menzionata, ha creato un interessante conglomerato di metodi che analizzano il fine della norma giuridica, permettono di svolgere un esame empirico del diritto in azione e di effettuare un'analisi storica e giuridica dell'evoluzione degli istituti giuridici. Il metodo ad ampio spettro di studio, adottato dal Professore, ha portato a creare una metodologia specifica per lo studio del diritto agrario. È un importante contributo alla dottrina del diritto in questione in Polonia. 